\title{
STUDI TENTANG KEGIATAN PENGEMBANGAN KOLEKSI (COLLECTION DEVELOPMENT) PADA PERPUSTAKAAN PERGURUAN TINGGI DI WILAYAH PRIANGAN TIMUR PROVINSI JAWA BARAT
}

\author{
Yunus Winoto*, dan Sukaesih*
}

Pengutipan: Winoto, Y., dan Sukaesih., (2016). Studi tentang kegiatan pengembangan koleksi (collection development) pada perpustakaan perguruan tinggi di Wilayah Priangan Timur Provinsi Jawa Barat. Khizanah Al-Hikmah Jurnal Ilmu Perpustakaan, Informasi, dan Kearsipan, 4(2), 118-129.

\section{*Staf pengajar pada Program Studi Ilmu Perpustakaan Fakultas Ilmu Komunikasi Universitas Padjajaran \\ (yunuswinoto@gmail.com)}

\begin{abstract}
ABSTRAK
Penelitian ini bertujuan untuk mengetahui kegiatan pengembangan koleksi pada perpustakaan perguruan tinggi di wilayah priangan timur Provinsi Jawa Barat. Lokasi penelitian ini dilakukan di UPT. Perpustakaan Siliwangi (UNSIL) Tasikmalaya dan UPT. Perpustakaan Universitas Galuh (UNIGAL) Ciamis. Fokus penelitian ini meliputi 6 (enam) aspek yakni aspek analisis kebutuhan, pembuatan kebijakan pengembangan koleksi, kegiatan seleksi, kegiatan pengadaan bahan pustaka, kegiatan penyiangan serta kegiatan evaluasi. Metode penelitian yang digunakan adalah metode deskriptif dengan jenis penelitian studi kasus. Untuk teknik pengumpulan datanya dilakukan melalui wawancara, observasi serta studi kepustakaan. Berdasarkan hasil penelitian diketahui bahwa UPT. Perpustakaan UNSIL Tasikmalaya dan UPT. Perpustakaan UNIGAL Ciamis pada umumnya telah melakukan tahapan-tahapan dalam pengembangan seperti analisis kebutuhan, pembuatan kebijakan seleksi, kegiatan seleksi, pengadaan bahan pustaka, serta melakukan evaluasi namun pelaksanaan belum dilakukan secara optimal. Sedangkan untuk tahapan penyiangan bahan pustaka UPT. Perpustakaan UNSIL Tasikmalaya dan UPT. Perpustakaan UNIGAL Ciamis belum melaksanakan dikarenakan menghadapi berbagai kendala antara masih terbatasnya koleksi yang dimiliki serta masalah prosedur dan keterbatasan sumber daya manusia (SDM) yang tersedia.
\end{abstract}

Kata Kunci: Perpustakaan Perguruan Tinggi, Pengembangan Koleksi, Koleksi

\section{ABSTRACT}

This study aims to determine the activities of collection development at the college library in the eastern Priangan West Java Province. The location of this research conducted in UPT. Siliwangi Library (UNSIL) Tasikmalaya and UPT. Galuh University Library (Unigal) Ciamis. The focus of this study include six (6) aspects, aspects of the needs analysis, policy-making collection development, selection activities, procurement of library materials, weeding activities and evaluation activities. The method used is descriptive method with case study. For data collecting technique is done through interviews, observation and literature study. Based on the survey results revealed that UPT. Library UNSIL Tasikmalaya and UPT. Library Unigal Ciamis in general has done the stages in development such as requirements analysis, policy making the selection, the selection, procurement of library materials, as well as to evaluate, but the implementation is not optimal. As for weeding stages UPT library materials. Library UNSIL Tasikmalaya and UPT. Library Unigal Ciamis has not carried out due to face many obstacles between the limited collection of owned and issue procedures and the limited human resources (HR) is available.

Keywords: University Library, Collection Development, Collection 


\section{PENDAHULUAN}

Perguruan tinggi merupakan suatu lembaga ilmiah yang proses kehidupannya adalah proses belajar mengajar, proses peningkatan kecerdasan yang dilandasi oleh akhlak yang tinggi. Sebagai suatu almamater perguruan tinggi adalah satu kesatuan yang bulat antara pengajar, karyawan, administrasi dan perpustakaan yang harus mampu melaksanakan fungsi tridarma perguruan tinggi yaitu : pendidikan, penelitian dan pengabdian pada masyarakat.

Sistem pendidikan di perguruan tinggi berfungsi untuk menghasilkan ilmuan yang memiliki keahlian dalam bidang tertentu, sehingga mampu membangun dirinya secara pribadi seutuhnya, serta mampu mengembangkan keilmuannya untuk turut serta dalam membangun bangsa dan negara.

Dukungan perpustakaan perguruan tinggi antara lain berupa penyediaan koleksi yang sesuai dengan kebutuhan mahasiswa (pengguna), titik temu antara koleksi dan kebutuhan ini menjadikan perpustakaan sebagai bagian integral dari kegiatan belajar mahasiswa. Sistem penelitian diarahkan kepada penemuan dan pengembangan teori, hukum atau kaidah, prinsip, informasi inferensi atau kegenerasi baru, atau pengujian kembali dan renovasi penemuan dan pengembangan terdahulu sehingga memberikan manfaat untuk keperluan menggambarkan, menerangkan, memprediksi bahkan mengenda-likan gejala-gejala alam, termasuk unsur manusia dengan budaya serta pikirannya.

Apabila merujuk pada pasal 106 Peraturan Pemerintah (PP) RI Nomor 30 tahun 1990 tentang pendidikan tinggi menyebutkan bahwa mahasiswa berhak memanfaatkan fasilitas belajar dalam rangka kelancaran proses belajar. Salah satu bentuk fasilitas itu adalah perpustakaan dan koleksi yang tersedia di dalamnya.

Hal ini sangat mendukung fungsi tridharma perguruan tinggi yang mengutamakan prestasi belajar atau jasa layanan langsung kepada masyarakat sebagai perwujudan konsepsi tentang kedudukan perguruan tinggi sebagai pusat budaya bangsa yang dapat berfungsi sebagai pemacu lajunya pembangunan bangsa dan negara.

Agar koleksi perpustakaan dapat dimanfaatkan sesuai dengan fungsinya, ada dua hal yang harus dimiliki oleh perpustakaan, pertama bahan pustaka yang sesuai dengan sumber daya yang tersedia sekaligus memenuhi kebutuhan pemakainya. Kedua, pustakawan yang berpengalaman dalam melakukan seleksi bahan pustaka dan mempunyai kemampuan dalam mengantisipasi kebutuhan informasi, minat dan selera pemakainya. Sesuai dengan pernyataan Soejono Trimo bahwa:

"Suatu perpustakaan dapat dikatakan berhasil dalam memberikan pelayanan kepada masyarakatnya. Bilamana masyarakat yang dila-yaninya merasa puas atas bahan-bahan yang tersedia dan koleksi tersebut benar-benar dipilih oleh pustakawan sesuai dengan kebutuhan, minat dan selera pembacanya." (Trimo, 1972:3).

Di perguruan tinggi, perpustakaan merupakan unit pelayanan teknis yang berafiliasi dengan perguruan tinggi dengan tujuan utama membantu 
perguruan tinggi mencapai tujuannya. Dengan demikian, perpustakaan perguruan tinggi bertujuan membantu melaksanakan tridarma perguruan tinggi dengan mahasiswa sebagai sasarannya.

Berbicara tentang perpustakaan perguruan tinggi, di wilayah Priangan Timur Provinsi Jawa Barat terdapat dua perguruan tinggi besar yakni Universitas Siliwangi (UNSIL) dan Universitas Galuh (UNIGAL) Ciamis. Adapun Universitas Siliwangi sebelumnya adalah merupakan perguruan tinggi swasta yang saat ini telah berubah statusnya menjadi perguruan tinggi negeri (PTN). Di Wilayah Provinsi Jawa Barat sebenarnya masih ada beberapa perguruan tinggi swasta lainnya lagi yang sedang diusulkan untuk menjadi perguruan tinggi negeri (PTN) misalnya Uswagati di Cirebon dan Universitas Karawang (UNSIKA).

Univerrsitas Galuh Ciamis yang menyelenggarakan pendidikan untuk jenjang D3, S1, Akta IV dan program pascasarjana (S2) mempunyai jumlah mahasiswa sekitar 5.402 orang dengan jumlah dosen tetap dan dosen luar biasa sebanyak 341 orang dengan kualifikasi pendidikannya mulai, sarjana (S1), S2, S3 dan profesor. Sedangkan Universitas Siliwangi yang mempunyai jumlah mahasiswa sebanyak 4.500 orang dengan jumlah dosen tetap sekitar 300 orang, (Sumber : UNIGAL dan UNSIL, 2014).

Dalam menunjang proses belajar mengajar yang berlangsung di kedua perguruan tinggi tersebut yakni UNSIL dan UNIGAL, dilengkapi dengan berbagai fasilitas, salah satunya adalah tersedianya perpusta-kaan. Dalam kegiatannya, perpustakaan tersebut diharapkan dapat memberikan pelayanan yang terbaik bagi seluruh sivitas akademika dengan menyediakan koleksi yang berkualitas dan sesuai dengan kebutuhan, minat dan selera daru para penggunanya (users).

Oleh karena itu berkaitan dengan paparan tersebut di atas, penulis tertarik untuk mengkaji tentang kegiatan pengembangan koleksi (collection development) yang dilakukan UPT. perpustakaan Universitas Siliwangi (UNSIL) dan UPT. Perpustakaan Universitas Galuh (UNIGAL) Ciamis.

\section{FOKUS PENELITIAN}

Berdasarkan latar belakang masalah tersebut, dapat dirumuskan masalah yaitu bagaimana kegiatan pengembangan koleksi (collection development) yang dilakukan UPT. Perpustakaan UNSIL Tasikmalaya dan UPT. Perpustakaan UNIGAL Ciamis?.

Kemudian dari rumusan masalah tersebut, penelitian ini difokuskan pada enam (6) aspek yakni :

1) Bagaimana kegiatan analisis kebutuhan (need analysis) masyarakat pengguna yang dilakukan UPT. Perpustakaan UNSIL dan UPT. Perpustakaan UNIGAL.

2) Bagaimana kegiatan penyusunan kebijakan pengembangan koleksi yang dilakukan UPT. Perpustakaan UNSIL dan UPT. Perpustakaan UNIGAL.

3) Bagaimana kegiatan seleksi (selection) bahan pustaka yang dilakukan UPT. PerpustakaanUNSIL dan UPT. Perpustakaan UNIGAL.

4) Bagaimana kegiatan pengadaan koleksi (acquisition) yang dilakukan 
UPT. Perpustakaan UNSIL dan UPT. Perpustakaan UNIGAL.

5) Bagaimana kegiatan penyiangan bahan pustaka (deselection) yang dilakukan UPT. Perpustakaan UNSIL dan UPT. Perpustakaan UNIGAL.

6) Bagaimana kegiatan evaluasi (evaluation) yang dilakukan UPT. Perpustakaan UNSIL dan UPT. Perpustakaan UNIGAL.

\section{TUJUAN DAN MANFAAT}

\section{a. Tujuan Penelitian}

Ada beberapa tujuan dari pelaksanaan penelitian ini yakni sebagai berikut:

1) Untuk mengetahui kegiatan analisis kebutuhan (need analysis) masyarakat pengguna yang dilakukan UPT. Perpustakaan Universitas Siliwangi (UNSIL) Tasikmalaya dan UPT. Perpustakaan Universitas Galuh (UNIGAL) Ciamis.

2) Untuk mengetahui kegiatan penyusunan kebijakan pengembangan koleksi yang dilakukan UPT. Perpustakaan Universitas Siliwangi (UNSIL) Tasikmalaya dan UPT. Perpustakaan Universitas Galuh (UNIGAL) Ciamis.

3) Untuk mengetahui kegiatan seleksi (selection) bahan pustaka yang dilakukan UPT. Perpustakaan Universitas Siliwangi (UNSIL) Tasikmalaya dan UPT. Perpustakaan Universitas Galuh (UNIGAL) Ciamis.

4) Untuk mengetahui kegiatan pengadaan koleksi (acquisition) yang dilakukan UPT. Perpustakaan Universitas Siliwangi (UNSIL) Tasikmalaya dan UPT. Perpustakaan Universitas Galuh (UNIGAL) Ciamis.

5) Untuk mengetahui kegiatan penyiangan bahan pustaka (deselection) yang dilakukan UPT.
Perpustakaan Universitas Siliwangi (UNSIL) Tasikmalaya dan UPT. Perpustakaan Universitas Galuh (UNIGAL) Ciamis.

6) Untuk kegiatan evaluasi (evaluation) yang dilakukan UPT. Perpustakaan Universitas Siliwangi (UNSIL) Tasikmalaya dan UPT. Perpustakaan Universitas Galuh (UNIGAL) Ciamis.

\section{b. Manfaat Penelitian}

Ada dua manfaat yang diharapkan dari penelitian ini yakni sebagai berikut :

1) Manfaat Teoritis. Dari hasil penelitian ini diharapkan dapat memberikan pengalaman ilmiah bagi kami dalam mengkaji lebih dalam tentang teori-teori pengembangan koleksi (collection development). Selain itu juga diharapkan dari hasil penelitian ini dapat memberikan masukan dalam pengayaan materi kuliah pengembangan koleksi.

2) Manfaat Praktis. Diharapkan dari hasil penelitian ini dapat memberikan masukan bagi pihak pengelola UPT. Perpustakaan Universitas Siliwangi (UNSIL) Tasikmalaya dan UPT. Perpustakaan Universitas Galuh (UNIGAL) Ciamis dalam meningkatkan pelayanan pada para penggunanya melalui kegiatan pengem-bangan koleksi yang berorientasi pada kebutuhan pengguna (user oriented).

\section{TINJAUAN KEPUSTAKAAN}

\section{a. Koleksi Perpustakaan Perguruan Tinggi}

Perpustakaan sebagai pusat informasi atau sumber belajar yang merupakan tempat terkumpulnya berbagai sumber 
informasi baik berupa buku, majalah, surat kabar dan berbagai koleksi lainnya. Berbicara tentang koleksi perpustakaan pada dasarnya koleksi perpustakaan perguruan tinggi terbagi dua, yaitu: koleksi tercetak dan tidak tercetak. Koleksi tercetak pada umumnya berbentuk buku, manunskrip, arsip, penerbitan berkala, penerbitan pemerintah dan microfiches. Jenis koleksi yang tidak tercetak antara lain: films, filmstrip, video tape, pita rekaman suara, piringan hitam, proyektor, globe dan AVA.

Menurut Soeatimah (1992), koleksi perpustakaan perguruan tinggi seyogyanya terdiri dari:

Buku referensi, baik referensi umum maupun untuk bidang studi khusus

Buku teks baik yang diperlukan oleh mahasiswa maupun dosen, baik yang diwajibkan untuk mata kuliah tertentu maupun yang dianjurkan. Buku teks adalah buku yang membahas suatu bidang ilmu tertentu yang ditulis dengan tujuan untuk memudahkan pemcapaian proses belajar mengajar antara guru dengan murid, antara mahasiswa dengan dosen

Buku untuk pengembangan ilmu yang melengkapi dan memperkaya pengetahuan diluar bidang studi yang ditekuni

Majalah ilmiah.

Koleksi media cetak non buku

Mengenai koleksi ini media cetak bukan buku ini adalah segala macam penerbitan yang dicetak, tetapi tidak berbentuk buku. Ada beberapa yang termasuk dalam kelompok ini seperti:

- Koran, brosur, pamphlet

- Penerbitan perguruan tinggi, baik penerbitan sendiri maupun penerbitan perguruan tinggi lain

- Penerbitan pemerintah, terutama produk hukum yang berkaitan dengan perguruan tinggi

- Laporan-laporan penelitian, terutama dari lembaga sendiri

- Skripsi, tesis, disertasi, teruma dari lembaga sendiri

Masih tentang koleksi perpustakaan menurut M. Idris Suryana (1983) koleksi tercetak dapat digolongkan kedalam bentuk buku dan koleksi khusus. Berdasarkan jenis dan tingkat informasi, bentuk, cakupan isi dan caya penyajiannya, maka jenis buku dikelompokkan menjadi tiga bagian, antara lain:

1) Buku ajar (text books) baik untuk dosen maupun untuk mahasiswa yang bermanfaat sebagai materi dalam proses belajar mengajar

2) Buku reference (rujukan), seperti encyclopedia, almanak, index, abstrak, tesis dan alat bantu penelusuran informasi lebih lanjut

3) Buku-buku bacaan pelengkap, baik untuk dosen, mahasiswa, karyawan yang bermanfaat untuk hiburan .

Sedangkan koleksi khusus menurut Lois Round Wilson sebagaimana yang dikutif Suryana (1998: 5) antara lain:

1) Skripsi, tesis dan disertasi yang sebagain besar merupakan hasil riset dan pembuktian hipotesis berdasarkan teori dan analisis 
seseorang untuk mencapai gelar pada suatu perguruan tinggi.

2) Manuskrip dan arsip sebagai sumber utama

Koleksi perpustakaan perguruan tinggi tidak hanya terbatas yang disebutkan di atas, berbagai koleksi multimedia pun dimiliki seperti CDROM, slide, film dan yang lainnya yang disebabkan oleh perkembagn media komunikasi yang semakin moderen.. Koleksi perpustakaan perguruan tinggi hendaknya bisa memenuhi kebutuhan informasi penggunanya serta menunjang dan memperlancar pelaksanaan pendidikan dan pengajaran.

\section{b. Konsep Pengembangan Koleksi}

Pengembangan koleksi merupakan salah kegiatan kerja perpustakaan yang bertugas menyediakan sumber informasi dan memberikan pelayanan informasi kepada pemakai sesuai dengan kebutuhan dan minat pemakainya (Soeatminah, 1992:66). Dengan kata lain pengembangan koleksi adalah suatu kegiatan mengidentifikasi kelebihan dan kelemahan koleksi yang dimiliki perpustakaan dengan mengaitkannya pada kebutuhan pengguna. Berkaitan dengan pengembangan koleksi Bernhard dalam Sinaga (2005) menyebutkan beberapa tujuan dari pengembangan koleksi yakni sebagai berikut :

1) Menambah jumlah koleksi atau mengharapkan untuk memilikinya.

2) Memperoleh koleksi yang di tulis oleh pengarang yang populer di kalangan pembaca.

3) Memenuhi kewajiban perpustakaan untuk menunjang pencapaian tujuan lembaga.

4) Menambah nilai koleksi melalui pengadaan bahan pustaka yang aktual dan bahan pustaka dasar dalam suatu subyek penting.

5) Memperoleh bahan-bahan pustaka atau buku-buku referensi yang mampu mensuplai informasi yang di butuhkan oleh pengguna.

6) Melengkapi informasi dalam subyek yang masih kurang atau belum ada sama sekali, atau belum mencukupi kebutuhan pemakai.

Masih tentang pengembangan koleksi, menurut Evans (2000 : 14) pengembangan koleksi adalah suatu kegiatan yang sifatnya cyclical atau terus menerus. Adapun mengenai proses pengembangan koleksi terdiri dari enam (6) tahapan yakni sebagai berikut :

1) Community analysis, atau disebut analisis masyarakat yaitu tahap awal proses pengembangan koleksi untuk melihat siapa segmentasi pemakai perpustakaan.

2) Kebijakan pengembangan koleksi, yaitu meliputi kebijakan perpustakaan untuk mengembangkan koleksi, mengarahkan dana, dan menempatkan jenis-jenis koleksi perpustakaan.

3) Seleksi, pada intinya adalah memilih bahan pustaka mana yang sesuai masuk ke perpustakaan sesuai dengan jenis perpustakaan.

4) Akuisisi, yaitu suatu proses kegiatan pengadaan bahan pustaka yang dilakukan dengan pembelian, hadiah, hibah, tukar menukar, menerbitkan sendiri, dan titipan.

5) Weeding, yatu kegiatan menyiangi bahan pustaka.

6) Evaluasi, yaitu kegiatan mengevaluasi koleksi yang ada di perpustakaan secara berkesinambungan. 
Apabila dari keenam (6) tahapan tersebut di atas digambarkan dapat dikemukakan sebagai berikut :

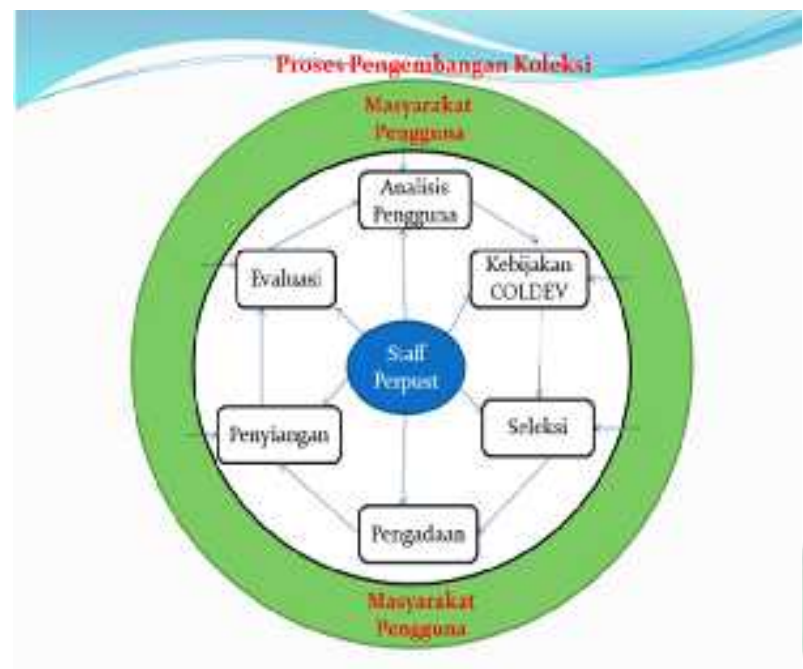

Gambar 1. Proses pengembangan koleksi

Berdasarkan gambar tersebut dalam proses pengembangan koleksi staf perpustakaan dalam melakukan pengembangan koleksi dimulai dengan melakukan analisis pengguna. Dalam setiap tahapan pengembangan koleksi kecuali pada tahapan pengadaan staf perpustakaan harus selalu memperhatikan siapa masyarakat penggunanya atau patron communitynya. Dalam konteks perpustakaan masyarakat pengguna ini dapat dibedakan menjadi potensial users dan aktual users. Adapun mengenai potensial users adalah masyakat yang seharusnya menjadi pengguna perpustakaan misalnya pada perpustakaan perguruan tinggi potensial user-nya adalah seluruh sivitas akademika perguruan tinggi dimana perpustakaan tersebut berada. Sedangkan aktual user adalah pengguna yang aktif menggunakan perpustakaan.

Kemudian mengenai keenam (6) tahapan dalam pengembangan koleksi, dapat dijelaskan sebagai berikut :

\section{1) Community analysis}

Ada beberapa istilah yang biasa dipakai untuk menjelaskan takapan ini, ada yang menyebutnya dengan istilah kajian pengguna, analisis kebutuhan serta ada yang menyebutnya analisis masyaraat. Namun demikian tahapan ini adalah merupakan yaitu tahap awal proses pengembangan koleksi untuk melihat siapa segmentasi pemakai perpustakaan. Dalam melakukan analisis kebutuhan pengguna ini dapat dilakukan secara formal maupun secara non formal. Secara formal dilakukan melalui penelitian langsung kepada pengguna/pemakai perpustakaan dengan melihat faktor : Sosial budaya, Tingkat pendidikan, Sosial ekonomi, Minat baca, Usia dan Jenis kelamin (L/P).

Sedangkan secara non formal dapat dilakukan dengan cara mengkaji berbagai terbitan dan sumber informasi yang ada untuk kepentingan pengguna. Intinya analisis masyarakat ini dilakukan untuk mendapatkan data yang akurat tentang kebutuhan informasi dari masyarakat/ pengguna yang akan dilayani oleh perpustakaan yang bersangkutan.

\section{2) Kebijakan Pengembangan Koleksi}

Kebijakan pengembangan koleksi ini menyangkut dokumen tertulis yang berkaitan dengan pengembangan koleksi. Dalam kebijakan ini biasanya menyangkut masalah bahan pustaka yang akan dikembangkan, anggaran/dana dan prioritas pengadaan jenis koleksi. Dalam tahapan ini sifatnya masih bersifat umum, misalnya menyangkut priotitas bahan pustaka yang akan diadakan, anggaran yang diusulkan, tim pengembangan koleksi yang terlibat, dll. Pembuatan kebijakan pengembangan koleksi 
mempunyai beberapa fungsi yakni sebagai pedoman bagi para selekstor, sebagai sarana komunikasi serta sebagai sarana perencanaan. Sedangkan dilihat dari manfaatnya kebijakan seleksi mempunyai beberapa manfaat yakni :

- Membantu dalammementapkan metode seleksi

- Membantu dalam cara untuk pengadaan koleksi

- Membantu dalam perencanaan anggaran

- Membantu dalam merencananakan kerjasama pengembangan koleksi.

- Membantu dalam melakukan perencaan penyiangan bahan pustaka.

\section{3) Seleksi Bahan Pustaka}

Kegiatan seleksi bahan pustaka adalah kegiatan yang sangat penting dalam pengembangan koleksi. Tersedianya suatu koleksi, baik secara kuantitatif maupun kualitatif merupakan suatu faktor yang menentukan keberhasilan penyelenggaraan suatu perpustakaan. Ada beberapa pengertian tentang seleksi bahan pustaka, Helen G. Heins dalam Yunus Winoto (2010) mengartikan seleksi sebagai kegiatan mensuplai bahan pustaka yang tepat kepada pembaca yang tepat dan dalam waktu yang tepat. Sedangkan M. Idris Suryana (1983:22) menyatakan seleksi adalah suatu upaya pustakawan dalam memilih koleksi perpustakaan yang tepat guna dan berhasil guna untuk memenuhi tujuan dan kebutuhan lembaga penaungnya.

Ada beberapa hal yang melatar belakangi perlunya kegiatan seleksi bahan pustaka. Berkaitan dengan hal ini minimal ada dua pendapat pakar perpustakaan yang bisa dijadikan pijakan yakni pendapat dari Jan Needle dalam Yunus
Winoto (2010) yang menyatakan bahwa bahan pustaka itu ada yang bersifat membangun dan ada juga yang bersifat merusak.Oleh karena itu tidak semua bahan pustaka dapat menjadi koleksi perpustakaan. Oleh karena itu seorang pustakawan harus mampu bertindak sebagai penyaring/penyeleksi informasi. Pendapat lainnya dikemukakan oleh Ranganathan dalam Yunus Winoto (2010) yang terkenal dengan 5 hukum perpustakaan, dimana salah satu hukumnya menyatakan bahwa perpustakaan merupakan organisma yang selalu tumbuh dan berkembang. Perkembangan dan pertumbuhan ini meliputi secara kuantitas maupun kualitas.

Berbicara lebih jauh tentang seleksi bahan pustaka, maka akan dikaitkan dengan beberapa hal seperti pendekatan dalam seleksi bahan pustaka, alat bantu seleksi sampai pada falsafah seleksi bahan pustaka. Adapun mengenai pendekatan seleksi Mc Colvin dalam Yunus Winoto (2010) menyatakan ada dua pendekatan teori seleksi yakni:

1) Teori nilai, teori pengembangan koleksi yang dilihat dari kacamata pustakawan dalam memandang penting tidaknya suatu informasi.

2) Teori permintaan, teori pengembangan koleksi dilihat dari permintaan pengguna. Koleksi yang dipilih harus sesuai dengan permintaan pemakai. Dalam teori ini pustakawan merespon kebutuhan pemakai.

\section{4) Akuisisi}

Akuisisi adalah suatu proses kegiatan pengadaan bahan pustaka yang dilakukan dengan pembelian, hadiah, hibah, tukar menukar, menerbitkan sendiri, dan 
titipan. Koleksi yang diadakan oleh suatu perpustakaan hendaknya relevan dengan minat dan kebutuhan, lengkap, dan terbitan mutakhir, agar tidak mengecewakan masyarakat yang dilayani. Kegiatan pengadaan merupakan suatu rangkaian dari mulai kegiatan pemesanan, pengadaan baik melalui pembelian, sumbangan/hibah, dll sampai dengan kegiatan administrasi lainnya.

\section{5) Penyiangan Bahan Pustaka (Weeding)}

Pengetian penyiangan atau weding adalah pemindahan koleksi yang tidak lagi digunakan oleh penggunnya. Penyiangan adalah sebagai kegiatan mengeluarkan atau menarik bahan pustaka dari rak yang disebabkan karena beberapa hal seperti eksemplarnya berlebih, kondisi fisik telah rusan berat, jarang dipakai, dan perkembangan ilmu pengetahuan. Penyiangan dimaksudkan untuk membentuk kumpulan bahan pustaka yang penting, relevan dan menarik. Penyiangan dilakukan atas asumsi bahwa nilai guna suatu bahan pustaka dapat dilihat dai penggunan bahan pustaka.

Penyiangan dilakukan atas dasar asumsi bahwa nilai guna suatu bahan pustaka dapat dilihat dari penggunaan bahan pustaka tersebut. Oleh karena itu koleksi yang kurang sekali penggunaannya dianggap sebagai koleksi yang tidak layak berada di rak perpustakaan atau harus dikeluarkan.

\section{6) Evaluasi}

Evaluasi merupakan kegiatan yang penting yang harus dilakukan di perpustakaan, melalui kegiatan evaluasi kita bisa megetahui bagaimana kea-daan perpustakaan. Evaluasi bisa dijadikan sebagai dasar untuk perbaikan koleksi, agar koleksi yang tersedia benar-benar membantu dan sesuai dengan kurikulum yang ada. Evaluasi dapat dilakukan dengan menentukan tujuannya yang berarti bahwa evaluasi direncanakan untuk mejawab pertanyaan tertentu dan data yang diperoleh memungkinkan untuk diperbaiki sistem yang ada. Tujuan evaluasi juga memungkinkan untuk kita untuk membuat keputusan yang terbaik tentang perpustakaan dengan cara mengidentifikasi

aspek-aspek perpustakaan yang mungkin perlu diperbaiki dan untuk mengidentifikasi fingsi-fungsi perpustakaan yang perlu dipercepat.

Dalam melakukan setiap tahapan dalam kegiatan pengembangan koleksi tersebut, staf perpus-takaan atau Tim pengembangan koleksi harus selalu memperhatikan siapa yang menjadi patron communitynya ada masyarakat penggunanya. Hal ini sangat penting karena setiap lembaga pengelola informasi, perpustakaan atau pusat-pusat informasi lainnya mempunya segment pengguna yang berbeda atau dengan kata lain setiap jenis perpustakaan mempunyai patron community yang berbeda. Untuk perpustakaan perguruan tinggi seperti UPT. Perpustakaan Universitas Siliwangi (UNSIL) dan UPT. Perpustakaan Universitas Galuh (UNIGAL) Ciamis patron comunitynya adalah para sivitas akademika yakni mahasiswa, dosen, dan karyawan dilingkungan perguruan tinggi tersebut. Selain itu juga faktor lainnya yang harus diperhatikan dari aspek yang terkait dengan patron community ini adalah jumlah mahasiswa, dosen, dan karyawan, banyaknya program studi, jenjang strata pendidikan, dll. 
Kemudian dari gambar tersebut, dari setiap tahapan kegiatan selain harus bersandar pada siapa yang menjadi patron communitynya juga setiap tahapan harus menjadi dasar untuk pelaksanaan pada tahapan selanjutnya. Misalnya setelah dilakukan tahapan analisis kebutuhan, sehingga diperoleh gambaran siapa profil pengguna dan bagaimana kebutuhan informasinya, maka pada tahap selanjutnya adalah menyusun kebijakan seleksi dalam menyediakan bahan pustaka yang dibutuhkan, prioritas bahan pustaka yang harus dibeli serta besarnya anggaran yang akan di usulkan, dll.

\section{METODOLOGI PENELITIAN}

\section{a. Metode Penelitian}

Dalam penelitian ini metode yang digunakan adalah metode penelitian deskriptif. Menurut Moh Nazir, (1999 : 63) metode deskriptif adalah suatu metode dalam meneliti status sekelompok manusia, suatu objek, suatu set kondisi, suatu sistem pemikiran ataupun suatu kelas peristiwa pada masa sekarang. Adapun tujuan penelitian deskriptif masih menurut Nazir (1999) adalah untuk membuat deskripsi, gambaran atau lukisan secara sistematis, faktual dan akurat mengenai fakta-fakta, sifat-sifat serta hubungan antar fenomena yang diselediki.

Kemudian mengenai jenis penelitian yang dilakukan adalah penelitian kasus atau studi kasus. Mengenai jenis penelitian kasus menurut Moh Nasir (1999) termasuk salah satu penelitian dalam lingkup metode deskriptif. Hal ini juga senada dengan pendapat Yatim Riyanto (1996 : 20) yang mengelompokkan studi kasus sebagai salah satu jenis penelitian dalam lingkup metode deskriptif. Masih tentang studi kasus Robert K Yin (2000:1) dalam bukunya, studi kasus : desain dan metode, menyebutkan bahwa studi kasus dapat dibedakan menjadi tiga tipe yaitu studi kasus ekplanatoris, studi kasus eksplorasi, dan studi kasus deskritif.

Pengertian penelitian kasus juga dikemukakan oleh Saifuddin Azwar (1997 : 8) yang menyatakan bawa studi kasus adalah merupakan penyelidikan mendalam (indepth study) mengenai suatu unit sosial sedemikian rupa sehingga menghasilkan gambaran yang terorganisasikan dengan baik dan lengkap mengenai unit sosial tersebut. Sedangkan tujuan dari penelitian kasus menurut Depdikbud Dirjen DIKTI sebagaimana dikutif Yatim Riyanto (1996) yaitu penelitian bertujuan untuk mempelajari secara intensif mengenai suatu unit sosial tertentu, yang meliputi individu, kelompok, lembaga dan masyarakat. Sedangkan menurut Moh. Nasir (1999 : 66) tujuan studi kasus adalah untuk memberikan gambaran secara mendetail tentang latar belakang, sifat-sifat serta karakter-karakter yang khas dari kasus, ataupun status dari individu yang kemudian dari sifat-sifat khas di atas akan dijadikan suatu hal yang bersifat umum.

\section{b. Sumber Data}

Sumber data dalam penelitian ini meliputi Kepala UPT. Perpustakaan Universitas Siliwangi (UNSIL) dan Kepala UPT. Perpustakaan Universitas Galuh (UNIGAL) Ciamis, staf di bagian pengembangan koleksi serta para pengunjung perpustakaan tersebut.

\section{c. Teknik Pengumpulan Data}

1) Observasi, berupa pengamatan langsung yang dilakukan di 
lapangan. Adapun kegiatan observasi yang kami lakukan adalah dengan mengamati proses pengembangan koleksi yang berjalan di kedua UPT. Perpustakaan Universitas Siliwangi (UNSIL) Tasikmalaya dan UPT. Perpustakaan Universitas Galuh (UNIGAL) Ciamis.

2) Wawancara, berupa pengumpulan informasi dan pendapat dari individu/ informan sebagai sumber penelitian yang menjadi data primer dalam penelitian yang dilakukan secara intensif dilaksana-kan dengan tanya jawab langsung.

3) Studi Kepustakaan, yaitu dengan mengkaji berbagai literatur baik dari media cetak seperti buku, majalah, jurnal, surat kabar dll, maupun dari media elektronik seperti dari internet, mengenai berbagai teori, tulisan dan hasil penelitian yang membahas tentang pengembangan koleksi (collection development).

\section{HASIL PENELITIAN}

a) Kegiatan analisis kebutuhan/analisis masyarakat, pada dasarnya sudah dilakukan pihak UPT. Perpustakaan Universitas Siliwangi (UNSIL) Tasikmalaya dan UPT. Perpustakaan Universitas Galuh (UNIGAL) Ciamis, hanya dalam pelaksanaanya masih dilakukan secara informal dan tidak terprogram, sehingga jika dijadikan bahan untuk tahap pengembangan koleksi selanjutnya datanya tidak lengkap dan tidak akuntabel.

b) Dalam menyusun kebijakan pengembangan koleksi sebenarnya sudah dilakukan pihak UPT. Perpustakaan Universitas Siliwangi
(UNSIL) Tasikmalaya dan UPT. Perpustakaan Universitas Galuh (UNIGAL) Ciamis, namun dalam penyusunan kebijakan pengembangan koleks masih belum memperhatikan variabel-variabel yang ada sehingga jumlah koleksi dan prioritas koleksi yang diusulkan kurang menggambarkan kebutuhan pengguna yang sebenarnya.

c) Dalam melakukan penyeleksian bahan pustaka yang dilakukan oleh pihak UPT. Perpustakaan Universitas Siliwangi (UNSIL) Tasikmalaya dan UPT. Perpustakaan Universitas Galuh (UNIGAL) Ciamis, alat bantu seleksi yang digunakan menggunakan daftar katalog penerbit dan pertimbangan pustakawan. Selain itu juga dalam melakukan seleksi bahan pustaka pihak UPT. Perpustakaan UNSIL dan UNIGAL bersandar pada pedoman seleksi bahan pustaka untuk perpustakaan perguruan tinggi.

d) Kegiatan pengadaan bahan pustaka yang telah dilakukan oleh pihak UPT. Perpustakaan Universitas Siliwangi (UNSIL) Tasikmalaya dan UPT. Perpustakaan Universitas Galuh (UNIGAL) Ciamis, dilakukan melalui pembelian baik langsung ke toko buku atau penerbit, melalui hibah/sumbangan, penggandaan atau fotocopy dan melalui kerjasama antar perpustakaan dan lembaga informasi lainnya.

e) Kegiatan penyiangan, sampai saat ini masih belum dilakukan oleh pihak UPT. Perpustakaan Universitas Siliwangi (UNSIL) Tasikmalaya dan UPT. Perpustakaan Universitas Galuh (UNIGAL) Ciamis, karena dihadapkan oleh 
berbagai kendala seperti masih terbatasnya koleksi.

f) Mengenai kegiatan evaluasi yang dilakukan pihak UPT. Perpustakaan Universitas Siliwangi (UNSIL) Tasikmalaya dan UPT. Perpustakaan Universitas Galuh (UNIGAL) Ciamis, sebenarnya telah dilakukan tapi sifatnya masih sederhana dan tidak terprogram serta tidak menggunakan parameter yang biasa dilakukan dalam melakukan evaluasi koleksi.

\section{DAFTAR PUSTAKA}

Azwar, Saifuddin, 1997. Metode Penelitian, Yogyakarta : Pustaka Pelajar.

Basuki, Sulistyo. 1991. Pengantar Ilmu Perpustakaan, Jakarta : Gramedia Pustaka Utama.

Daryanto, 1986. Pengetahuan Praktis bagi pustakawan. Bandung : Bina Cipta.

Departemen Pendidikan dan

Kebudayaan RI. 1994.

Perpustakaan Perguruan Tinggi :

Buku Pedoman. Jakarta :

Departemen Pendidikan dan

Kebudayaan RI.

Evans, G Edward and Margaret Zarnosky

Saponaro. 2005. Developing

Library and Information Center

Collection.New York : Library unlimited. 2005.

Evans, G Edward. 2000. Developing Library and Information Center Collection. New York: Library unlimited.

H.S, Lasa. 1990. Kamus Istilah Perpustakaan Yogyakarta:

Kanisius.

Katz, William A. 1989. Collection development: the selection of material for library.New York : Holt Renehart and Winston.

Nasir, Moh. Metode Penelitian, Ghalia Indone, Jakarta, 1999.

Moleong, Lexy J. 1989. Metode Penelitian Kualitatif. Bandung : Rosda Karya.

Nasution, S. 1988. Metode Penelitian Naturalistik Kualitatif. 1988, Bandung : Tarsito.

Rianto, Yatim. 1996. Metode Penelitian Kependidikan, Surabaya : SIC.

Soeatminah.

Perpustakaan kepustakawanan

Pustakawan.1992. dan Kanisius,

Suryana, Idris. 1993. Menyeleksi Pustaka Yang Tapat guna Untuk perpustakaan Perguruan Tinggi, Bandung : IKIP.

Trimo, Soejono.. 1990. Pedoman pelaksanaan perpustakaan. Bandung. : Remaja Rosdakarya

Yulia, Yuyu ; Janti G. Sujana dan Henny Windarti, 1994. Materi Pokok Pengadaan Bahan Pustaka. Jakarta; UT. 